DOI: 10.46340/eppd.2021.8.1.22

\author{
Vasyl Popkov, ScD in Philosophy \\ ORCID ID: https://orcid.org/0000-0002-4284-6747 \\ Roman Serov \\ ORCID ID: https://orcid.org/0000-0001-9146-1264 \\ Odessa I.I. Mechnikov National University, Ukraine

\section{UKRAINIAN-FRENCH DISCOURSE: PECULIARITIES OF POLITICAL REALITY INTERPRETATIONS}

\author{
Василь Попков, д. філос. н. \\ Роман Серов \\ Одеський національний університет імені І.І.Мечникова, Україна

\section{УКРАЇНСЬКО-ФРАНЦУЗЬКИЙ ДИСКУРС: ОСОБЛИВОСТІ ІНТЕРПРЕТАЦІЙ ПОЛІТИЧНОЇ РЕАЛЬНОСТІ}

The article is an analysis of how bilateral relations between Ukraine and France are developing, to what extention the features of the French and Ukrainian political mentality affect the nature of these relations. The work is based on the methodology of comparative historical, systemic and structural-functional analysis, phenomenological and psychological methods, the mode of symbolic interactionism; civilizational, anthropological, sociological approach, and hermeneutic tools are also used.

The article focuses on the key issues of the Ukrainian-French discourse: the extension, depth and pace of Ukraine's integration into the European Union; the nature of relations between Ukraine and North Atlantic Treaty Organization, the possibilities of returning Ukraine to the status of a nuclear power, the problem of disproportions between the high level of Ukraine and France political and diplomatic consultations and the low level of French investment and innovation activity in the Ukrainian business environment.

Ukrainian foreign policy (including the French direction) can become more effective if its domestic policy changes qualitatively. Here one can prioritize;

a) political management, the transition from "extraverted" (orientation towards external management) to "introverted" (orientation towards internal management);

b) the use of external borrowings as an active resource for internal socio-economic growth;

c) creation of open conditions for creative self-realization of all social and ethnic groups of Ukrainian society;

d) formation of an attractive Ukrainian investment climate;

e) (as a result) the creation of an attractive model of the political organization of society and a high quality of life, strengthening of international authority and prestige.

Keywords: Ukrainian-French discourse, France, Ukraine, NATO, European Union, nuclear status.

Вступ. За три десятиліття українсько-французьких стосунків склалася повноцінна система двосторонньої співпраці. Проте в політичному діалозі виникало декілька тем, які стали предметом багаторічних і не завжди результативних дискусій. Ця тема набула особливої актуальності на початку 20-х років нашого століття, коли в Європейському співтоваристві 3 новою силою активізувалися переговори з приводу ступеня і глибини інтеграції України в ЄС. Ці питання, серед яких українськофранцузьки відносини є приоритетними, мають стратегічно важливе значення для сучасної України.

Мета та завдання дослідження зводяться до аналізу основних змістовних чинників інтерпретацій політичної реальності українськими та французькими політиками які відзначені 
розбіжністю смислів. Також метою дослідження є пошук засобів розв'язання смислових розбіжностей в інтересах покращення двосторонніх відносин Україна - Франщія. Особливої уваги заслуговують події, відмічені не тільки відсутністю міждержавної партнерської солідарності, а й звісною протидією в просуванні України в наднаціональні міжнародні структури і проекти, перш за все в СС і НАТО.

Методологія. Для досягнення поставленої мети автори застосували метод порівняльноісторичного аналізу. У цьому ключі було проаналізовано період від початку співробітництва двох країн - до теперішнього часу. (протягом майже трьох десятиліть). Хронологічно він поділений на три етапи: 1991-2005 pp., 2005-2014рр. та період революційних подій з 2014 р.

При дослідженні проблем українсько-французького дискурсу застосований системний метод, що дозволяє розглядати міждержавній політичний діалог як складну систему, визначувану специфікою політичної культури, геополітичного положення, стратегічних підходів до міжнародної політики (і т. д.) кожної з держав.

Разом з системним методом був застосований метод структурно-функціонального аналізу, що дозволяє вивчати предмет наукового дослідження з двох сторін : а) з точки зору вивчення структури україно-французьких стосунків в контексті глобальних системных процесів, і б) з точки зору вивчення поведінки кожної із структурних складових частин украино- французького політичного дискурсу.

В якості специфічного підходу був застосований метод символічного интеракционизма, грунтований на теорії Джоуль. Мида і Ч. Кулі, що розглядали будь-яке співтовариство як сукупність взаємодій акторів, які за допомогою певних символів (слів, жестів, знаків і т. д.), вступають в интеракции і тим самим "творять" світ. В якості своеобразного символічного "интеракционистского світу" в нашому випадку виступає сфера україно-французьких стосунків, що має свої значення і свою символіку.

У дослідженнях сенсу подій та інтерпретацій $\epsilon$ раціональним використання феноменологічного методу, грунтованому на філософії Гуссерля і соціальної феноменології Шютца. Суспільство в їх уявленні $є$ сукупність феноменів (однією своєю частиною тих, що належать суб'єктивному світу індивіда, інший - світу об'єктивному). Індивід орієнтується в об'єктивній реальності і взаємодіє з іншими індивідами за допомогою індивідуальних уявлень про зовнішній світ і суб'єктивних вражень, що "приходять" з внутрішнього життєвого досвіду. Досвід українофранцузьких стосунків також значною мірою є феноменологічним, поєднуючи аналіз об'єктивних процесів з суб'єктивними переживаннями життєвих "біографій" обох країн.

Був застосований і психологічний підхід, суть якого зводиться до пізнання соціальної реальності виходячи з суб'єктивного бачення цієї реальності акторами політичного процесу, поміщеним в певні соціально-політичні умови, певне психологічне середовище ("психологія народів" М. Лацаруса, В. Вундта, "психологія мас" С. Сигеле, м. Лебона, "психологія инстинктивизма" У. МакДугала, дослідження 3. Фрейда, Х. Ортеги-и-Гассета, Э. Фромма, Т. Адорно та ін.). Такий підхід дозволяє глибше зрозуміти характер різночитань в україно-французьких стосунках.

Різні соціально-політичні умови, різні культурні і соціально-психологічні середовища не можуть не позначатися на характері взаємовідносин між двома державами. Серйозне наукове дослідження не може обійтися і без антропологічного підходу - дослідження політичних процесів і механізмів управління на основі людського виміру політики, тобто обліку якостей людини як біосоціальної істоти (інстинкти, стійкі риси інтелекту, психіки, особливості національного характеру). Безумовно, "людський чинник" активно впливає і на процес україно-французьких стосунків, як, втім, і на увесь комплекс міжнародних відносин в глобальному співтоваристві.

Завжди науково затребуваним $є$ і соціологічний підхід - дослідження соціальної реальності 3 т.3. інтересів складових іiї соціальних груп, з т.з. соціальної структури досліджуваного предмета, а також з т.з. соціального статусу і ролей, що граються індивідами в тому або іншому співтоваристві. Цілком зрозуміло, що в особі Франції і України представлені соціальні структури, що розрізняються, різні статусні і ролеві мережі, різні групи інтересів і впливу. Ця соціологічна реальність не можпет не позначитися на особливостях політичних, економічних, дипломатичних і т. д. стосунків між Україною і Францією.

Сукупність цих методологічних підходів при аналізі текстів документів і публікацій доповнена застосуванням інструментарію герменевтичної інтерпретації.

I, нарешті, не можна не враховувати вплив цивілізаційного чинника на політичний діалог України і Франції. I хоча Україна усіма силами прагне стати повноправним членом Європейського 
Союзу, для французьких партнерів вона залишається носієм іншого культурного коду. Ще у кінці XX століття С. Хантингтон писав про "тріщину цивілізаційного розлому", яка розколола на дві нерівні частини українське суспільство. На українському заході домінує западно-христианский цивілізаційний код, на сході - східно-християнський, православний. Ця культурно-цивілізаційна обставина не може не враховувати французька сторона. На основі приведеного тут методологічного комплексу і выстраиватеся ця стаття.

Виклад. Практично з самого початку здобуття незалежності Україна чітко сформулювала європейські пріоритети своєї зовнішньої політики.

Підписання у 1992 р. Договору про взаєморозуміння та співробітництво між Україною і Французькою Республікою ${ }^{1}$ створило правову основу розвитку співробітництва в політичній, економічній, культурній та науковій галузях. Визначено, що "Україна і Французька Республіка будуть брати участь у побудові мирної та єдиної Європи. 3 цією метою вони будуть розвивати своє політичне співробітництво як на двосторонньому, так і багатосторонньому рівнях." (Ст. 2), "Французька Республіка зобов'язується сприяти розвитку тісних зв'язків між Україною і Європейськими співтовариствами. ... сприяти вступу України до Ради Європи, який вона розглядає як важливий фактор інтеграції України в об’єднану Європу" (Ст. 6).Ці позиції були закріплені у Постанові Верховної Ради України "Про Основні напрями зовнішньої політики України"(1993р.) , а нову, заключну редакцію отримали у Законі України "Про засади внутрішньої і зовнішньої політики"(2010p.). де було ясно позначене прагнення домагатися вступу в Свропейський союз. Законодавець розумів, що це не буде швидким і одноразовим політичним актом, тому затвердив курс на укладання Угоди про партнерство та співробітництво, здійснення якого "послужить першим етапом просування до асоційованого, а згодом до повного її членства у цій організації"(Розд. III, п.2.) ${ }^{2}$, Це принциповій момент, бо формат партнерства на платформі угоди про асоціацію з $\mathrm{CC}$, яку запровадила саме Франція у 2007 році, була передбачена українською доктриною ще за півтора десятиліття до того. Однак, мотиви та уявлення сторін щодо сенсу асоціації зовсім не збігалися. Для українських політиків це уявлялося природним кроком поетапного просування до повноправного членства в Євросоюзі. Але Франція надала цьому визначенню зовсім інший сенс, бо, як показали подальші події, робила вона це з метою припинення розширення СС. 3 наведеного вище тексту Договору від 1992 року випливало, що Франція висловила готовність сприяти розвитку тісних зв'язків між Україною і Європейськими співтовариствами, та «сприяти вступу України до ради Європи», що вона дійсно зробила, але зобов'язань по частині членства в СС не було. Крім того, з моменту підписання договору Україна зіткнулася з несподіваною перешкодою. Верховна Рада України ратифікувала договір без всяких зволікань, але з французької сторони аналогічних дій не упосліджувало. Через рік після підписання цього Договору посольство України повідомляло:"Французька сторона досі зволікає 3 процедурою його ратифікації, не надаючи нам 3 цього приводу жодного обгрунтованого пояснення"”. 3 цього приводу наше посольство змушено було також зробити зауваження та надати урок дипломатичної грамоти парламентаріям, вказавши, що "не синхронізована $з$ французькою стороною у строках ратифікація нашою Верховною Радою згаданого документу поставила Україну у досить принизливе становище в контексті ії двосторонніх стосунків з Францією. 3 точки зору існуючої міжнародної практики, висловлення згоди на обов'язковий характер такого роду документів має здійснюватися обома сторонами без значного розриву у часі, інакше це може негативно впливати на загальну атмосферу двосторонніх відносин і мати небажані політичні наслідки". 4

Таким чином, перше франиузьке «Ні» не мало ніякого вербального формулювання. Ніхто не відмовляв, але і не вирішував питання про ратифікацію. Без пояснень. Пауза затягнулася на роки, заповнюючи очікування малозрозумілими інтерпретаціями французьких посадовців. Вичікувальна позиція, зайнята керівництвом Франції щодо розбудови стосунків з Україною, пояснювалася то наявністю на нашій території ядерної зброї, то загрозою Чорнобилю, неначе при підписанні договору

\footnotetext{
${ }^{1}$ Договор про взаєморозуміння та співробітництво між Україною і Франиузькою Республікою, 1992 (Україна; Французька Республіка). Відомості ВР України, 43, 612.

${ }^{2}$ Постанова про Основні напрями зовнішньої політики України, 1993 (Верховна Рада України). Відомості Верховної Ради Украӥни, 37, 379.

${ }^{3}$ Дутчак, Г. (2017). Етапи становлення і розвитку українсько-французького культурного співробітництва. Электронная Библиотека boOk.net $<\mathrm{http} / /$ bo0k.net/index.php?p=achapter\&bid=19364\&chapter=1> (2021, січень, 15).

${ }^{4}$ Серов, Р. І. (2018). Українсько-французькі відносини: політологічний вимір у історичній ретроспективі.

Політикус, 5/6, 15-25.
} 
це було невідомо. Були й інші версії французьких політиків, відтворені журналісткою А. Лазаревой: «Коли розмова заходить на цю тему в принципі, французи завжди підкреслюють, що механізм ратифікації у Франції займає часом і два, і три роки», сесії парламенту тривають недовго, накопичується стільки і внутрішніх, і зовнішніх невирішених проблем, що «проголосувати за все фізично не вистачає часу» ${ }^{1}$. Коли в грудні 1994 року Президент України Л.Кучма запитав про це Президента Франції Ф. Міттерана, той не вважав доречним відтворювати вищевказану версію (всетаки вже йшов третій рік затягування процедури), а пообіцяв, що навесні ратифікація відбудеться. Але минув і третій рік - нічого не сталося, хоч на той момент вже де факто відбулося ядерне роззброєння України, згідно з Будапештським меморандумом 1994 року.

Це тривало майже 4 роки. Договір, підписаний у червні 1992 року, був ратифікований Національними зборами Франції тільки 14 лютого 1996 року.

Що змушувало французів вичікувати? Спробуємо надати свою інтерпретацію цього явища. Французька дипломатія вибудовувала свої стосунки з новими партнерами зі Східної Свропи 3 оглядкою на Росію. України це стосувалося в першу чергу, бо договору з Росією, такого, як з Францією, Україна в 1992 році ще не мала. Тільки 25 листопада 1995 року були підписані міждержавні угоди, що стали прологом до Великого договору з РФ (Договір про дружбу, співробітництво і партнерство між Україною і Російською Федерацією). Лише через рік після цього, коли йшла кінцева фаза узгоджень умов Договору Києва 3 Москвою, Франція ратифікувала свій договір з Україною.

3 архівних джерел можна дознатися, яких зусиль коштувало українським дипломатам входження до французького і європейського політикуму у якості рівноправного партнера. Так, в першому звіті Посольства України у ФР за 1993 рік дуже точно помічені особливості підходу французів до нової ситуації. Ось витяг з цієї характеристики:"...французький уряд з самого початку надав в системі цих стосунків пріоритет відносинам з Росією, що по суті є продовженням традиційної проросійської орієнтації Франції у східноєвропейській політиці. ...поява на європейській арені ще однієї держави, яка за своїми розмірами і потенціалом дорівнює Франції, а крім того має на своій території ядерну зброю, означає необхідність потіснитися за столом великих європейських націй, щоб дати Україні ії законне місце. ...зіткнення двох тенденцій французької політики - реалістичної та традиційної - призводить до ситуації, коли реальні кроки французької дипломатії по відношенню до нашої держави не завжди відповідають проголошеним принципам." 2 .

3 такою «невідповідністю проголошеним принципам» Україна зіткнеться ще не раз, але потрібно помітити, що французьке "ні" завжди можна було пояснити i, до речі, це було не завжди всупереч інтересам України, як би це могло спочатку здаватися. Ось яскравий приклад. У ті ж роки йшли напружені перемовини між Україною, США, Великобританією та Росією щодо ядерного роззброєння України. У перемовинах брали участь також Франція та КНР, хоч підписантами Будапештського меморандуму вони не були. На заключному етапі президенти України та Франції Л.Кучма і Ф.Міттеран мали приватну бесіду, де останній попередив украинского президента щодо гарантій Україні з боку великих держав. «Вас обдурять»-сказав великодосвідчений Ф.Міттеран.Таким чином, він ясно підказав українському президентові необхідність твердого «ні» документу з незрозумілими гарантіями безпеки і ніякими зобов'язаннями по компенсаціях за відмову від найдорожчого активу держави.

Л.Кучма неодноразово згадував цей епізод³, а свою недовіру до попередження французького президента пояснював тим, що не міг уявити собі такого цинізму від глав світових держав А ось Ф.Міттеран уявляв це цілком виразно. Чи була ймовірність отримати підтримку Франції, якби Україна твердо наполягала на наданні реальних гарантій і гідних компенсацій? Pourquoi pas - чому б ні? Франція брала участь в переговорах, хоч і не була в числі підписантів Будапештського меморандуму, до якого вона приєдналася окремим документом. В усякому разі, була можливість витребувати для країни хоч щось відчутне. На це питання немає відповіді, тому що такі вимоги не були виставлені.

Дискусія із цього приводу з новою силою гостро розгорнулася в Україні з 2014 року. I справа не в 20-й річниці меморандуму, а в новій політичній реальності. Колишній посол США в Україні Стивен Пфайфер прокоментував наслідки Будапештського меморандуму так: "I якби в 1993-

\footnotetext{
1 Лазарева, А. (1995). Рождение «французского мифа» ожидается этой весной». Зеркало Недели, 9.

${ }^{2}$ Архів МЗС України,фонд Посольства України у ФР, Спр.023, Л.2.

${ }^{3}$ Украинская правда (2009). Кучма: еще Миттеран говорил не верить гарантиям безопасности

<https://www.pravda.com.ua/rus/news/2009/10/25/4509844/> (2021, січень, 15).
} 
1994 роках Кравчук і Кучма могли передбачити події 2014 року, вони напевно не погодилися б на підписання Будапешта". Він також підкреслив, що Будапештський меморандум не містив ніяких гарантій безпеки і "США дуже чітко дали зрозуміти це українській владі в 1994 році"1. Проте, це трактування категорично відкидають не лише українські політологи, але і ряд їх зарубіжних колег. Наприклад, в публікації О. Білоколоса тема міжнародних гарантій розглянута в історичній ретроспективі ${ }^{2}$. Він послався на погляди французького історика дипломатії Жана-Батіста Дюрозеля, висловлені в книзі "Історія дипломатії з 1919 р. до наших днів" про Пакт загальної відмови від війни 1928 року? (Пакт Бріана-Келога), який можна вважати апогеєм дипломатії "пактоманіi". На думку Дюрозеля, це була небезпечна ілюзія. Простеживши низку таких гарантій, в тому числі від імені СБ ООН і НАТО у відношенні України, автор статті розкритикував реанімацію цієї ілюзії, а саме, напад «пактоманіi» тодішнього міністра закордонних справ П.Клімкіна, який озвучив «Українській правді» 20.07.2014 р. незрозумілу ідею «перехресних гарантій безпеки».

3 іншого боку, ряд українських аналітиків наполягали, що Будапештський меморандум не порожній аркуш, а повноцінний міжнародний договір. Ретельний аналіз його проведено в статті П.Жовніренко, який доводить, що згідно з нормами міжнародного права він не потребував ратифікації і є обов'язковим до виконання'.

Таку ж позицію відстоюють і ряд французьких аналітиків. Наприклад, науковий співробітник Французького інституту геополітики та Інституту

Томаса Мора Ж - С. Монгренье переконаний, що домовленості в Будапешті лягли в основу міжнародного права, а спроби їх дезавуювати - «гра в софістику» ${ }^{4}$. Незважаючи на міжнародний резонанс цієї теми, ніяких практичних наслідків з боку США, Англії та Росії не наступило.

Але крім політичних дискусій, українську громадськість стало все більше цікавити питання неотримання компенсацій від підписантів меморандуму за втрачену зброю та військове майно гігантської вартості. Після оновлення Мінських перемовин у 2020 роци, голову української делегації екс-президента Л.Кучму змінів екс-президент Л.Кравчук, якій одразу заявив, що підписанти Будапештского меморандуму 1994 року отримали з України ядерну зброю та інші компоненти вартістью 300 млрд доларів, а тому повинні реально допомагати Україні в вирішенні питань

Донбасу і Криму5. 3 точки зору історичної справедливості така постановка питання цілком доречна. Однак, громадськість хвилюють більш практичні питання, яки досі залишаються без відповіді. Наприклад, чому всупереч Лісабонським угодами про скорочення ядерного арсеналу, Україна погодилася на його повну ліквідацію? Чому Україна підписала меморандум за ілюзорні зобов'язання безпеки, не вимагаючи реальних фінансових компенсацій вартості ракетних шахт, боєголовок, стратегічних ракет і бомбардувальників? Чому замість обумовлених 7 років на демонтаж і вивіз ядерних комплексів в 2 етапи, вивезення було спішно завершено за рік? і т.д. В той же час, інформаційний простір України знову заповнився дискусіями і проектами щодо перепідписання Будапештського меморандуму в новій редакції із залученням додаткових гарантів (ФРН, Польщі та ін.). Але доки світові держави не реагують на ці пропозиції, тому вони залишаються «бурею в склянці води». Одним з найбільш складних і суперечливих напрямів українсько-французького політичного діалогу упродовж усіх років є дискусія про євроатлантичну інтеграчію, про членство Украӥни в СС $i$ HАTO. Кардинальну розбіжність в інтерпретації цього тренду в українсько-французькому дискурсі ми вже відмітили на прикладі перших офіційних документів. До цієї теми зверталися багато авторів і вона $€$ досі актуальною. Цей конфлікт інтересів не раз створював напруженість в політичних контактах.

Під час 4-го саміту Україна-ЄС у вересні 2000 року на зустрічі з Ж. Шираком Л.Кучма висловив сподівання українського політикуму щодо прагнення України до ЄС , вважая, що бачить у Франції

\footnotetext{
${ }^{1}$ Сегодня (2018). Екс-посол США розповів, як підписували Будапештський меморандум $<$ https://politics.segodnya.ua/politics/eks-posol-ssha-rasskazal-kak-podpisyvali-budapeshtskiy-memorandum-1148056.html> (2021, січень, 15).

2 Белоколос, О. (2014). Некоторые размышления о Будапештском меморандуме и международных гарантиях... Зеркало недели,. 45.

3 Жовниренко, П. (2019). Апология Будапештского меморандума. День, 30.07.2019.

${ }^{4}$ Монгренье, Ж. (2014). Мир - річ значно тендітніша, ніж здається. Texty.org.ua

$<$ https://texty.org.ua/fragments/52264/Myr_rich_znachno_tenditnisha_nizh_zdajetsa-> (2021, січень, 15).

5 Заяц, П. (2020). Кравчук назвал два своих первых шага на переговорах по Донбассу. Украина24

$<$ https://ukraina24.segodnya.ua/vlast-news/3337-kravchuk-nazval-dva-svoih-pervyh-shaga-na-peregovorah-po-donbassu> (2021, січень, 15).
} 
партнера, який може реалізувати цей план. За підсумками саміту була підписана Спільна заява Президента України Л.Кучми та Президента Ради Європи Ж.Ширака․․ Таким чином, ці відносини розглядалися не в останню чергу з точки зору можливостей Франції в просуванні євроінтеграційних інтересівУкраїни. Така інтерпретація була прийнятою в українському суспільстві, демонструючи неабияку стійкість багато років. У той же час, у «Спільній заяві» йшлося лише про широкий спектр питань взаємодії України з державами - членами СС і державами-кандидатами, з міжнародними організаціями, а також про необхідні реформи у різноманітних галузях соціально-економічного внутрішньополітичного життя. Але жодного плану дій щзодо отримання Украӥною членства в СС не обговорювалось, як і у «Спільній стратегії Європейського Союзу щодо України», яка була схвалена ще до цього.

Те, що наші двосторонні відносини не набули тієї дієвості, яка б відкрила для України ворота до $\mathrm{CC}$, треба розглядати не тільки як тиск російських пріоритетів франиузького керівництва. На думку українських дослідників,"красномовним прикладом може служити концептуальний підхід певних французьких кругів до євроінтеграції України. На думку одного українського дипломата, коли французи роками пропонували Україні асоціацію з СС, українці інтерпретували це як можливість укласти угоду асоціації з Свросоюзом, тоді як франиузи мали на увазі двосторонні програми співпраиі України з країнами СС. Зокрема, навесні 2003 року в Афінах президент Жак Ширак пропонував Україні саме цей шлях (який раніше пройшли країни Балтії). ... На жаль, французькі зусилля не оцінили належним чином"2.

У 2000-2004 роках політичні відносини України і Франиузької республіки також мали затримки у розвитку. Ряд гучних скандалів, що трапилися в 2001-2002 роках, негативно позначилися на політичному імиджі країни $\mathrm{i}$ відносинах із зарубіжними партнерами. У західній пресі чісленні інтерпретації з цього приводу (наприклад, т, зв. «кольчужний скандал») мали негативний характер. Прямим наслідком цього інформаційного тиску було рішення політичного керівництваУкраїни підтримати амеріканське вторгнення в Ірак, що, до речи, не підтримувала Франція. Але згодом ситуація знов вирівнялась. У 2004-2005 гг. українсько-французький політичний діалог набув певного поглиблення, зміцнилося співробітництво в торгівельно-економічній, військовій та військово-технічній сферах. Спостерігалося поліпшення умов діяльності французьких бізнесменів в Україні (нашу країну було переведено 37 до 6 групи ризиків) ${ }^{3}$.

На важкому шляху євроінтеграції України були не лише перешкоди, але $i$ успіхи. Найбільш значний з них був пов'язаний з ім'ям Ж.Ширака, який не лише радив, але в 2005 році після перемовин 3 українським Президентом В. Ющенко реально поставив двосторонню співпрацю на рейки Дорожсніх карт українсько-французьких стосунків. Цей проект працював до 2015 року і дав фантастичний приклад двосторонньої співпраці, особливо у інвестиційної сфері, коли у перший же рік показник інвестицій Франції в Україну сягнув у 9,5 разів (з 87,9 млн.дол. США до 830,3 млн доларів і надалі до 2012 року у середньому щорічні темпи приросту інвестицій зростали більш, ніж на 30 відсотків, поки несподівано не загальмувалися з поки що невідомих причин. ${ }^{4}$.

На тлі цих оптимістичних явищ Бухарестський саміт НАТО 2-3 квітня 2008 року став крижаним душем для українського політичного керівництва. Йшлося про надання Україні і Грузії так званного ПДЧ (Плану дій до вступу у члени НАТО). Стосовно перспектив відносин України з НАТО Франція демонструвала прихильність до принципів «відкритих дверей», але, у той же час дотримання поетапності у просуванні інтеграційного поступу до альянсу. Франція виступила проти приєднання України до ПДЧ, заявивши про передчасність такого кроку. Водночас вона підтримала політичне рішення щодо надання нашій країні перспективи членства в альянсі. Проте це рішення так i залишилося на папері. Ще напередодні саміту французькі урядовці не раз висловлювали застереження проти підписання ПДЧ із Україною, мотивуючи це внутрішньою неготовністю України піднятись на новий рівень партнерства з альянсом і негативними наслідками такого кроку для наявного балансу сил на європейському континенті, а також недоречністю використання вступу

\footnotetext{
1 Зібрання міжнародних договорів та інших документів (2010). Украйна - Свропейський Союз (1991-2009). Київ: Юстиніан, 495-498.

${ }^{2}$ Митрофанова, О. (2008). Перипетии французско-украинского диалога и перспективы евроинтеграции. Зеркало недели, 47.

${ }^{3}$ Архів 1-го СД МЗС України, Ф.ПУФР,2004, Довідка.

${ }^{4}$ Серов, Р. І. (2017). Українсько-французький політологічний дискурс в дзеркалі «Аудиту зовнішньої політики України». Вісник Одеського національного Університету. Сочіологія і політичні наукі, 22, 2 (29).
} 
до НАТО як «певного інструменту для розв'язання проблем, які існують в Україні у відносинах з одним iї потужним сусідом». ${ }^{1}$ На саміті у Бухаресті Україні і Грузії всупереч впевненим очікуванням, яки спирались на підтримку США, не було надано ПДЧ .

Ініціатором такого рішення була саме Франція, підтримана Німеччиною, а потім ще шістьма країнами. Проте, В. Ющенко на прес-конференції заявив, що таке рішення "навіть перевищило очікування" української сторони. Перенесення цього питання на обговорення міністрамі закордонних справ держав-членів НАТО на грудень він характеризував як політичний компроміс і навіть «коректну формулу перемоги» ${ }^{2}$. Я хочу відверто сказати, - підкреслив він, - однозначно сказати, що Франція $є$ нашим другом і партнером, коли ми говоримо про тему приєднання України до ПДЧ і майбутнє членство України в НАТО". Але матеріали того ж номера газети повні інших інтерпретацій українських політиків, які вважали це зовнішньополітичним провалом. Аналогічні відгуки прозвучали і в інших виданнях, наприклад у газеті «Сегодня», де більшість українських аналітиків прямим текстом вважали підсумки саміту для України повним фіаско ${ }^{3}$. У гнучкій інтерпретації Н.Саркозі Україна та Грузія «мають покликання» приєднатися до НАТО, але йдеться лише про їхню політичну готовність та терміни майбутнього приєднання. Є згадки очевидців, що сам В.Ющенко розумів сенс події. Підкреслена фраза «хочу відверто сказати, однозначно сказати, що Франція $є$ нашим другом і партнером» швидше за все, була гіркою іронією. У всякому разі, з президентом Н.Саркозі він більше не зустрічався. Ця тема не зникла з часом і постійно виникає в українській пресі.Але негативна реакція Росії - не єдиний $\mathrm{i}$ не головний мотив для Франції в цьому питанні. Навпаки, представники французького уряду наголошували, що у відносинах із Росією «гра у сфери впливу припинилася».

Турбуючись про свої лідерські позиції в Свропі, французи завжди уважно ставляться щодо посилення впливу Білого дому на європейські справи, а з Україною в НАТО вплив США зросте. У цьому інтереси Парижа і Берліна збіглися. До того ж, у французів був ще інший мотив, а саме, ревниве ставлення до ролі Німеччини на континенті, яка також має великий вплив на українське керівництво.

Необхідно зважати також на французьке бачення процесу реформування НАТО, надання пріоритету зміцненню автономних європейських механізмів безпеки, а також традиційно притаманне французькій дипломатії прагнення до підтримання рівноваги сил. До того ж, шлях до ЄС необов'язково йде через НАТО - декілька держав-членів $Є С$ не $є$ членами НАТО. Враховуючи американській вплив на українську політичну еліту, Франція скептично ставилася до використання механізмів євроатлантичної інтеграції України, і не тільки до НАТО, але й для сприяння інтеграції нашої держави в $Є С$. Таким чином, французька інтерпретація не лише $\epsilon$ формулою мови. Керівництво України недооцінювало її політичний сенс, помилково вважаючи, що підтримка США $є$ достатньою умовою для зміни позиції всіх, хто не чекає її вступу до НАТО. Не допомогли навіть проамериканські настрої Н.Саркозі. Додамо, що політичне керівництво НАТО взяло тоді до відома позицію Росії, висловлену міністром закордонних справ РФ С.Лавровым послові США У.Д.Бернсу: «Ви розумієте, що значить «ні»?». Посол Бернс сказав «так». І Лавров сказав: «Ні- означає - ні. У нас є червона лінія.... Навіть не думайте про те, щоб прийняти Україну і Грузію в НАТО». Після зустрічі, 1 вересня 2008 року посол направив у Вашингтон депешу з позначкою"Терміново" i 3 незвичайною назвою:"Ні означає ні: червоні лінії Росії відносно розширення НАТО"

У 2016 році на сайті аналітичної компанії «Українська призма» були опубліковані підсумки опитування 50 експертів-політологів, дипломатів, міжнародників про досягнення та невдачі зовнішньої політики країни за 25 років незалежності, де другим найбільшим провалом (після підписання Будапештського меморандуму 1994 р.) було відзначено фіаско на Бухарестському саміті НАТО в 2008 р. ${ }^{5}$. Але, на наш погляд, трактування $є$ надто прямолінійним і однобічним. Із питання вступу в НАТО консенсусу в українському і європейському суспільстві як не було, так і немає. Цей факт був відзначений в Бухаресті в якості однієї з причин відмови у видачі ПДЧ. 3 тих пір в Україні змінилися чотири президенти, але віз і нині там. Питання не вирішене, бо це було неможливо і

\footnotetext{
${ }^{1}$ Манжола, В., Шаповалова, О. (2008). Політична інновація французької дипломатії. Зовнішні сnрави, 11, $10-14$.

${ }^{2}$ Корреспондент.net (2008). Ющенко оиенивает итоги саммита НАТО как победу для Украинь

$<$ https://korrespondent.net/ukraine/politics/423500-yushchenko-ocenivaet-itogi-sammita-nato-kak-pobedu-dlya-ukrainy> (2021, січень, 15).

3 Чаленко, А. (2008). Провал президента. Вот тебе и ПДЧ...Вот тебе и НАТО... Сегодня, 3 aпреля.

4 День (2014). Меморандум для Ангель Меркель, 09.01.

${ }^{5}$ Українська призма (2016). Незалежність. $<$ http://prismua.org/independence/, 24/08/2016> (2021, січень, 15).
} 
перебувало поза зоною досяжності української дипломатії. Це одне з найбільших «Ні», яке закрило Україні реалізацію одного з головних зовнішньополітичних проектів, хоч варіантів конструктивного співробітництва з НАТО менше не стало.

На новому історичному етапі - 2014 року українсько-французький політичний діалог набув величезної інтенсивності. На відміну від відносного затишшя прямих контактів попередніх трьох років, на цій ділянці стався справжній вибух активності. Відносини президентів і урядів обох країн досягли високого ступеня політичної єдності i взаєморозуміння. Це був дійсний успіх зовнішньополітичної діяльності України на французькому напрямку у найбільш критичний для України час. У звіті МЗС щодо виконання "Дорожньої карті"українсько-французьких відносин на 2013-2015 роки відзначалося, що у 2014 році офіційний Париж займав активну позицію у світлі міжнародних заходів із врегулювання військової напруги та стабілізації соціально-політичної ситуації в Україні. 3 початку 2014 року Президент Франції Ф. Олланд провів 47 офіційних зустрічей i телефонних бесід із лідерами країн світу та главами міжнародних організацій, основною темою яких була ситуація в Україні.Після президентських виборів в Україні Ф. Олланд та П. Порошенко мали 4 офіційні зустрічі та 16 телефонних розмов, у тому числі у багатосторонньому форматі. Події в Україні також стали предметом 23 офіційних заяв. Серед найбільш знакових політичних контактів перших років, яки мали гучні політичні наслідки слід відокремити такі:-6 червня 2014 року робочий візит Президента України П. Порошенко до Франції для участі у заходов з нагоди 70-ї річниці висадки союзницьких військ у Нормандії. За ініціативою Ф.Оланда започатковано «нормандського формату» переговорів щодо врегулювання ситуації в Україні; 4-5 вересня в Уельсі відбулася двостороння зустріч Президентів України та Франції у рамок саміту НАТО. У цьому контексті слід також розглядати і політичне рішення Ф.Олланда призупинити поставку Росії військово-десантного вертольотоносного судна типу «Містарль». Це було майже неймовірною подією, так як замовлення було вже частково оплаченим і російський екіпаж прибув до Франції для тренувань і прийому судна.

Традиційні контакти парламентарів обох країн теж мали позитивні політичні наслідки. Досягнуто домовленостей щодо сприяння направлення в Україну французьких БПЛА для Спеціальної спостережної місії ОБСЄ, а також пришвидшення ратифікації Францією Угоди про асоціацію між Україною та ЄС. Франція була співавтором щодо підготовки проектів на захист територіальної цілісності та суверенітету України у рамок роботи ЮНЕСКО та Міжнародної організації Франкофонії ${ }^{1}$. Подальша спільна робота в рамках Нормандського формату, не привела до позитивних результатів у подоланні політичної кризи на Донбасі і українсько-російського конфлікту, але отримала широкий резонанс усвітовому співтоваристві, у світовій пресі, зробивши Україну важливим суб'єктом європейської політики.

На шляху до ЄС Україні вдалося просунутися до важливого рубежу.

Оприлюднена 3 грудня 2008 року та позитивно оцінена Радою Європи.

Комунікація Єврокомісії щодо «Східного партнерства» (СП) засвідчила переосмислення європейськими структурами політики сусідства, а також розуміння Євросоюзом необхідності поглиблення відносин із країнами СНД в умовах неможливості запропонувати їм перспективу членства в організації. Формалізація «Східного партнерства» відбулася під час головування Чехії в СС 7 травня 2009 року на інавгураційному саміті у Празі у форматі «27+6». Україна за сприянням Франції активно долучалася до підготовки та остаточного оформлення проекту разом із країнами-ініціаторами та Єврокомісією.

Офіційний Париж розраховував, що угоду про асоціацію між Україною та ЄС буде підписано протягом найближчих років, виступав за створення якомога ширшої зони вільної торгівлі між Україною та Свросоюзом. У цьому зв'язку особливо важливими сферами для обох країн традиційно вважались сільське господарство, енергетика, літакобудування, автомобілебудування, транспорт тощо. Однак перебіг подій розгортався у подальшому за іншим сценарієм. Мета була досягнута, але майже за 7 років, через бурхливі політичні події в Україні та збройний конфлікт. Й тільки 1 січня 2016 року Зона вільної торгівлі Україна-СС почала своє офіційне існування.

У переговоров на вищому рівні у процесі та після укладання Угоди про асоціацію між Україною та $\mathrm{CC}$ неодноразово оголошувались наміри України наполягати на чіткому визначенні європейської

\footnotetext{
${ }^{1}$ Поточний архів 1-го ЄД (2015). Щодо стану виконання у II півріччі 2014 р. Дорожньої карти між Україною та Франиузькою Республікою на період 2013-2015, 1, 2.
} 
перспективи членства в організації, відрізняючи цей договір від інших угод про асоціацію, підписаних $\mathrm{EC}$ із північноафриканськими країнами. Пропозиція була цілком логічною. Як на це реагувала офіційна Франція? Український посол в Парижі О.Шамшур в інтерв'ю «Укрінформ» в 2015 р. повідомляв про негативне ставлення французів до перспективи членства.

України в НАТО і СС. Під час обговорення ратифікації Угоди про асоціацію в обох палатах парламенту Франції «робився акцент на тому, що Угода про асоціацію не $\epsilon$ перехідним етапом до вступу України в СС і не передбачає ніяких перспектив членства» ${ }^{1}$. У котрий раз французи повторили це і у 2020 році без проблисків інших інтерпретацій. За повідомленням УНІАН, офіційний Париж заявив, що Франція не хоче, щоб "Східне партнерство" сприяло ймовірності майбутнього членства в СС. Партнерство виключає "всі перспективи або всі механізми інтеграції ЄС, або членства". Президент наполягає, що розширенню повинно передувати реформування СС в його нинішніх кордонах ${ }^{2}$. У газеті «Фігаро» читаємо: президент розраховує повернути Франції іiі історичну роль «держави-посередника» у світових проблемах, вважає, що «за існуючих умов перебудови світу було б помилкою не розмовляти с Росією, що б вона приєдналася до Європи, а не до Китаю». Президент підкреслив актуальність «переосмислення Європейського цивілізаційного проекту» ${ }^{3}$. Як бачимо, тут ціла програма, у якій чутні відгомони ідей де Голля. Але усі ці амбіційні політичні завдання знов опускають шлагбаум перед Україною. Знову велике "Нi", яке повертає головний стратегічний проект на об'їзну дорогу довжиною в роки. Порівнюючи інтерпретації політичної реальності в українсько-французькому дискурсі 2005 і 2014 років, зауважимо, що зовні обидві кризи пов'язані з відстороненням В. Януковича від президентства. В обох випадках французький політикум висловлював гарячу солідарність щодо євроатлантизму Майданів. Однак їх наслідки показали разючий контраст. Після переговорів в 2005 р. президентів В.Ющенка та Ж.Ширака двосторонні відносини були поставлені на рейки Дорожніх карт українсько-французького співробітництва з надзвичайним ефектом. Зокрема, показник торгово-економічних відносин збільшився у рази, а обсяг інвестицій в Україну - на порядок. Але після другого Майдану ми бачимо абсолютно новий сценарій. Політичний діалог піднявся до небувалих висот. Це не зупинило конфлікт на Донбасі, але сприяло підписанню Угоди про асоціацію України з СС, створення ЕвроЗЕС і надання «безвізу» для українців. Але парадокс у тому, що в економічних стосунках стався відкат на багато років назад. В цьому відмінність підсумків Майданів. С й «об'єднуючий» неприємний результат. Франщія обидва рази припинила спроби Украӥни увійти до ЄС і НАТО.

У цьому сенсі представляє інтерес точка зору журналіста французької газети" La Tribune" Емануеля Грішпана, стаття якого була підготовлена за результатами робочого візиту європейських лідерів думок до України, який був організований Інститутом світової політикиу у Києві. Ось декілька висловів із його статті "Погляд на Україну з Франції: як вийти з полону російських міфів?":... голос України ледве чутний у французькихЗМІ, чого не скажеш про голос Кремля. ... Наміри Путіна для рядового француза зрозумілі - він хоче збільшити свою територію, свій вплив, тоді як позиція України викликає питання. Так ризикувати (і отримати війну), щоб приєднатися до Європейського союзу? Жителям Франції в це важко повірити. Заяви українських чиновників про те, що Україна захищає Європу, стримуючи російську агресію, не сприймаються серйозно. Французи вважають, що їм несуть небезпеку зовсім інші речі: "Ісламська держава", тероризм, імміграці». ${ }^{4}$

Після оголошення про відновлення роботи Нормандської четвіркифранцузька преса знову повернулася до української теми. 3 можливих перешкод досягненню прогресу преса називала проблему інтерпретації «формули Штайнмайера». Але упідсумку президент В.Зеленський підтвердив попередні домовленості. Проте у ЗМІ знову активно стало питання про перегляд мінських угод, з натяками, що Макрон і Меркель допускають таку можливість. Чи це так? 30 березня 2020 року Міністерство Європи та закордонних справ Франції оприлюднило спільну заяву міністрів

\footnotetext{
${ }^{1}$ Посольство Федеративної Республіки Німеччина Київ (2020). Спільна заява Міністрів закордонних справ Франції та Німеччини щзодо конфлікту на Сході Украйни <https://kiew.diplo.de/ua-uk/aktuelles/-/2329784> (2021, січень, 15).

${ }^{2}$ Шамшур, О. (2015). Франция - против вступления Украины в НАТО, - посол. Аnостроф

$<$ https://apostrophe.ua/news/world/2015-07-06/frantsiya-protiv-vstupleniya-ukrainyi-v-nato---posol/28882> (2021, січень, 15).

${ }^{3}$ LeFigaro (2019). Politique <https://www.lefigaro.fr/politique $>$ (2021, січень, 15).

${ }^{4}$ Грішпан, Е. (2015). Погляд на Україну з Франції: як вийти з полону російських міфів? Європейська правда <http: //www. eurointegration.com.ua /rus/articles/ 2015 /07/31 /7036487/> (2021, січень, 15).
} 
закордонних справ ФР та ФРН відносно України, де закликають до виконання спільних висновків останнього саміту у Парижі «шляхом повного виконання Мінських домовленостей» ${ }^{1}$. Таким чином, зафіксована не тільки спекулятивність інтерпретацій, а й чергове «Ні» альтернативам умов «Нормандського формату».

В українсько-французькому дискурсі, особливо у публікаціях 3МI, постійно є присутнім аксіоматичний українсько-російський конфлікт; його численні інтерпретації з будь-якого приводу відтягують значний інтелектуальний потенціал дослідників, «звільняючи» їх від послідовного формування сенсу нової парадигми відносин з Францією.

Вважаємо, що українсько-французький консенсус з відновленням переговорів в Нормандському форматі може перевести відносини на новий рівень. Українська дипломатія мусить виконати важке завдання пошуку життєздатних рішень по Донбасу для узгодження всіма сторонами перемовин. І дуже важливо не дозволити популістам різних типів нав'язувати свій порядок мислення професійним політичним експертам.

\section{Висновки і пропозиції.}

1. У інтерпретаціях політичної реальності українсько-французького дискурсу періоди будівництва повноцінної системи двосторонньої співпраці представлені різноманітними трактуваннями з обох боків, що показали великий потенціал взаємовигідних стосунків і серйозні протиріччя в оцінках місця України в новій конструкції Європи.Подвійне відношення Франції до євроінтеграційних прагнень України поставило на повістку нове стратегічне бачення, яке Україна доки не сформулювала.Тому висока інтенсивність політичного діалогу на вищому рівні після 2014 року не привела до створення нової платформи двосторонніх стосунків, породжуючи в інформаційному просторі нові, іноді дівакуваті моделі політичних дій, грунтуючись на нових трактуваннях давніх подій.

2. Приведені в цій статті констатації певних розбіжностей в позциях Франції і України 3 питання про місце і роль України в Свропейському Союзі і НАТО не продиктовані мотивами ворожості або настороженості в стосунках менжду двома європейськими державами. Вони - наслідок різного положення і геополітичних пріоритетів обох країн в глобальній системі міжнародних відносин. Франція - сильна європейська суверенна держава, з багатовіковою історією. Вона позиціонує себе як "крайній європейський Захід" (після британського "брекзита"), як один з головних стабілізаторів європейського процесу. Україна ж розглядається як "крайній європейський Схід", джерело політичної турбулентності і нестабільності. Цим передусім пояснюється стриманість французької дипломатії з питання про "форсований" вступ України в СС і НАТО.

3. Позначаються і фундаментальні відмінності в геополітичних домаганнях Франції і України. Якщо Франція продовжує сприймати себе в контексті наполеоновско-голлисткой моделі "Свропи від Лісабона до Владивостока", то геополітичні амбіції України зводяться до скромного "вступу до Свропи" за узгодженням з іiі "грандами" (Франції і ФРН). У такому контексті Франція, (втім як і інші великі держави) схильна бачити в Україні швидше лимитрофну державу (між Європою і Росією), чим активного і самостійного суб'єкта європейського політичного процесу. У своїй політичній грі Францію вважає за краще мати справу передусім з великими геополітичними гравцями (такими як США, Німеччина, Росія, Китай), Цим, зокрема, пояснюється скепсис французької громадськості 3 приводу заяв українських лідерів про Україну як "форпост демократії" і "захисника Європи від ворожих полчищ".

4. Саме така різниця положень Франції і України в структурі світової політики значною мірою визначає існування основних "проблемних вузлів" в україно-французькому дискурсі. Це: міра, глибина і темпи інтеграції України в СС; питання про характер взаємовідносин по лінії Україна - НАТО; позиція 3 питання про недопущення України до володіння зброєю масового ураження; проблема диспропорції між високим рівнем політико-дипломатичних консультацій по лінії Францію - Україна і низьким рівнем французької інвестиційно-ділової активності в українському економічному середовищі.

5. В той же час $\epsilon$ приклади позитивного досвіду, напрацьованого в практиці українофранцузьких стосунків. До їх числа слід віднести практикові запропонованою Ж.Шираком "дорожніх карт» французько-українського співробітництва, які можна узяти за основу при розробці програм розвитку взаємовідносин не тільки по лінії Україна-Франція, але і Україна-СС.

\footnotetext{
${ }^{1}$ УНИАН (2020). Во Франции не хотят, чтобы "Восточное партнерство" способствовало будущему членству в ЕС - СМИ $<$ https://www.unian.net/politics/10847972-vo-francinehotyat-chtoby-vostochnoe-partnerstvosposobstvovalo-budushchemu-chlenstvu-v-es-smi.html $>$ (2021, січень, 15).
} 
Не менш цікавий досвід "нормандського формату", який при усіх його внутрішніх проблемах і протиріччях може стати платформою для врегулювання складних і багатофакторних регіональних проблем.

6. Українська зовнішня політика (у тому числі щодо Франції) може стати набагато ефективнішою, якщо якісно зміниться їі внутрішня політика. В якості основних "маркерів" цієї политики ми бачимо:

a) перехід від "экстравертивного" (орієнтація на зовнішнє управління) до "интравертивному" (орієнтація на внутрішнє управління) політичному менеджменту;

б) використання зовнішніх запозичень як активного ресурсу внутрішнього соціальноекономічного розвитку;

в) створення відкритих умов для своболной творчої самореалізації усіх соціальних і етнічних груп українського суспільства;

г) забезпечення привабливого українського інвестиційного клімату;

д) (Як результат) створення привабливої моделі політичної організації суспільства і високої якості життя, зміцнення міжнародного авторитету і престижу, повернення втрачених територій i політичних позицій.

\section{References:}

1. LeFigaro (2019). Politique [Politics] <https://www.lefigaro.fr/politique> (2021, January, 15). [in French].

2. Arkhiv 1-ho YED MZS Ukrayiny, F.PUFR,2004 [Archive of the 1st ED of the Ministry of Foreign Affairs of Ukraine, F. PUFR, 2004], Dovidka [Reference]. [in Ukrainian].

3. Arkhiv MZS Ukrayiny, fond Posolstva Ukrayiny u FR [Archive of the Ministry of Foreign Affairs of Ukraine, the fund of the Embassy of Ukraine in the FR], Spr.023, L.2. [in Ukrainian].

4. Belokolos, O. (2014). Nekotoryye razmyshleniya o Budapeshtskom memorandume i mezhdunarodnykh garantiyakh... [Some reflections on the Budapest memorandum and international guarantees ...] Zerkalo nedeli [Mirror of the week], 45. [in Ukrainian].

5. Hrishpan, E. (2015). Pohlyad na Ukrayinu z Frantsiyi: yak vyyty z polonu rosiyskykh mifiv? [A look at Ukraine from France: how to get out of the captivity of Russian myths?] Yevropeyska pravda [European truth] <http: //www. eurointegration.com.ua /rus/articles/ 2015 /07/31/7036487/> (2021, January, 15). [in Ukrainian].

6. Den (2014) [Day (2014)]. Memorandum dlya Angely Merkel [Memorandum for Angela Merkel], 09.01.

7. Dohovor pro vzayemorozuminnya ta spivrobitnytstvo mizh Ukrayinoyu i Frantsuzkoyu Respublikoyu, 1992 (Ukrayina; Frantsuzka Respublika) [Agreement on Mutual Understanding and Cooperation between Ukraine and the French Republic, 1992 (Ukraine; French Republic)]. Vidomosti VR Ukrayiny [Information of the Verkhovna Rada of Ukraine], 43, 612. [in Ukrainian].

8. Dutchak, H. (2017). Etapy stanovlennya i rozvytku ukrayinsko-frantsuzkoho kulturnoho spivrobitnytstva [Stages of formation and development of Ukrainian-French cultural cooperation]. Elektronnaya Byblyoteka boOk.net [Electronic Library boOk.net] <http://bo0k.net/index.php?p=achapter\&bid=19364\&chapter=1> (2021, January, 15). [in Ukrainian].

9. Zhovnirenko, P. (2019). Apologiya Budapeshtskogo memoranduma [Apology for the Budapest Memorandum]. Den [Day], 30.07. [in Ukrainian].

10. Zayats, P. (2020). Kravchuk nazval dva svoikh pervykh shaga na peregovorakh po Donbassu [Kravchuk named his two first steps in the negotiations on Donbass]. Ukraina24 [Ukraine24] <https://ukraina24.segodnya.ua/ vlast-news/3337-kravchuk-nazval-dva-svoih-pervyh-shaga-na-peregovorah-po-donbassu> (2021, January, 15). [in Ukrainian].

11. Zibrannya mizhnarodnykh dohovoriv ta inshykh dokumentiv (2010) [Collection of international treaties and other documents (2010)]. Ukrayina - Yevropeyskyy Soyuz (1991-2009). [Ukraine - European Union (1991-2009). Kyiv: Justinian 495-498. [in Ukrainian].

12. Korrespondent.net (2008) [Correspondent.net (2008)]. Yushchenko otsenivayet itogi sammita NATO kak pobedu dlya Ukrainy [Yushchenko assesses the results of the NATO summit as a victory for Ukraine] $<$ https://korrespondent.net/ukraine/politics/423500-yushchenko-ocenivaet-itogi-sammita-nato-kak-pobedu-dlyaukrainy> (2021, January, 15). [in Ukrainian].

13. Lazareva, A. (1995). Rozhdeniye «frantsuzskogo mifa» ozhidayetsya etoy vesnoy» [The birth of the "French myth" is expected this spring. "]. Zerkalo Nedeli [Mirror of the Week], 9. [in Ukrainian].

14. Manzhola, V., Shapovalova, O. (2008). Politychna innovatsiya frantsuzkoyi dyplomatiyi [Political innovation of French diplomacy]. Zovnishni spravy [Foreign affairs], 11, 10-14. [in Ukrainian].

15. Mitrofanova, O. (2008). Peripetii frantsuzsko-ukrainskogo dialoga i perspektivy yevrointegratsii [The ups and downs of the French-Ukrainian dialogue and the prospects for European integration]. Zerkalo nedeli [Mirror of the week], 47. [in Ukrainian]. 
16. Monhrene, Zh. (2014). Myr - rich znachno tenditnisha, nizh zdayetsya [Peace is a much more fragile thing than it seems]. Texty.org.ua $<\mathrm{https}$ ://texty.org.ua/fragments/52264/Myr_rich_znachno_tenditnisha_nizh_zdajetsa-> (2021, January, 15). [in Ukrainian].

17. Posolstvo Federatyvnoyi Respubliky Nimechchyna Kyiv (2020) [Embassy of the Federal Republic of Germany Kyiv (2020)]. Spilna zayava Ministriv zakordonnykh sprav Frantsiyi ta Nimechchyny shchodo konfliktu na Skhodi Ukrayiny [Joint statement of the Foreign Ministers of France and Germany on the conflict in eastern Ukraine] $<$ https://kiew.diplo.de/ua-uk/aktuelles/-/2329784> (2021, January, 15). [in Ukrainian].

18. Postanova pro Osnovni napryamy zovnishnoyi polityky Ukrayiny, 1993 (Verkhovna Rada Ukrayiny) [Resolution on the Main Directions of Ukraine's Foreign Policy, 1993 (Verkhovna Rada of Ukraine)]. Vidomosti Verkhovnoyi Rady Ukrayiny [Information of the Verkhovna Rada of Ukraine], 37, 379. [in Ukrainian].

19. Potochnyy arkhiv 1-ho YED (2015) [Current archive of the 1st ED (2015)]. Shchodo stanu vykonannya u II pivrichchi 2014 r. Dorozhnoyi karty mizh Ukrayinoyu ta Frantsuz'koyu Respublikoyu na period 2013-2015 [Regarding the state of implementation in the second half of 2014 of the Roadmap between Ukraine and the French Republic for the period 2013-2015], 1, 2. [in Ukrainian].

20. Sehodnya (2018) [Today (2018)]. Eks-posol SSHA rozpoviv, yak pidpysuvaly Budapeshtskyy memorandum [The former US ambassador told how the Budapest Memorandum was signed] $<$ https://politics.segodnya.ua/politics/eks-posol-ssha-rasskazal-kak-podpisyvali-budapeshtskiy-memorandum1148056.html> (2021, January, 15). [in Ukrainian].

21. Serov, R. I. (2017). Ukrayinsko-frantsuzkyy politolohichnyy dyskurs v dzerkali «Audytu zovnishnoyi polityky Ukrayiny» [Ukrainian-French political science discourse in the mirror of the "Foreign Policy Audit of Ukraine"]. Visnyk Odeskoho natsionalnoho Universytetu. Sotsiolohiya i politychni nauki [Bulletin of Odessa National University. Sociology and political science], 22, 2 (29). [in Ukrainian].

22. Serov, R. I. (2018). Ukrayinsko-frantsuzki vidnosyny: politolohichnyy vymir u istorychniy retrospektyvi [Ukrainian-French relations: political science dimension in historical retrospect]. Politykus [Politicus], 5/6, 15-25. [in Ukrainian].

23. Ukrainskaya pravda (2009) [Ukrainian truth (2009)]. Kuchma: yeshche Mitteran govoril ne verit garantiyam bezopasnosti [Kuchma: even Mitterrand said not to believe security guarantees] <https://www.pravda.com.ua/rus/news/2009/10/25/4509844/> (2021, January, 15). [in Ukrainian].

24. Ukrayinska pryzma (2016) [Ukrainian Prism (2016)]. Nezalezhnist [Independence]. $<\mathrm{http}: / /$ prismua.org/independence/, 24/08/2016> (2021, January, 15). [in Ukrainian].

25. UNIAN (2020). Vo Frantsii ne khotyat, chtoby "Vostochnoye partnerstvo" sposobstvovalo budushchemu chlenstvu $v \mathrm{YeS}-\mathrm{SMI}$ [France does not want Eastern Partnership to promote future EU membership - media] $<$ https://www.unian.net/politics/10847972-vo-francinehotyat-chtoby-vostochnoe-partnerstvo-sposobstvovalobudushchemu-chlenstvu-v-es-smi.html $>$ (2021, January, 15). [in Russian].

26. Chalenko, A. (2008). Proval prezidenta. Vot tebe i PDCH... Vot tebe i NATO... [The failure of the president. So much for the MAP ... So much for NATO ...] Segodnya, 03.04 [Today, April, 03]. [in Russian].

27. Shamshur, O. (2015). Frantsiya - protiv vstupleniya Ukrainy v NATO, - posol [France is against Ukraine's accession to NATO, - the ambassador]. Apostrof [Apostrophe] <https://apostrophe.ua/news/world/2015-07-06/ frantsiya-protiv-vstupleniya-ukrainyi-v-nato---posol/28882> (2021, January, 15). [in Russian]. 